\title{
Strategi Menjaga Keharmonisan Rumah Tangga Jarak Jauh Perspektif Pesepak Bola Profesional Klub Jakarta Matador FC
}

\author{
Ainur Rofiq ${ }^{1}$ \\ ${ }^{1}$ Fakultas Syariah, IAIN Jember. E-mail: ainur7rofiq@gmail.com
}

\begin{tabular}{|c|c|}
\hline Article & Abstract \\
\hline $\begin{array}{l}\text { How to cite: } \\
\text { Ainur Rofiq, 'Strategi } \\
\text { Menjaga Keharmonisan } \\
\text { Rumah Tangga Jarak } \\
\text { Jauh Perspektif Pesepak } \\
\text { Bola Profesional Klub } \\
\text { Jakarta Matador FC' Vol. } \\
1 \text { No. } 1 \text { Rechtenstudent } \\
\text { Journal Fakultas Syariah } \\
\text { IAIN Jember. } \\
\text { Histori artikel: } \\
\text { Submit } 14 \text { Februari 2020; } \\
\text { Diterima } 20 \text { Maret 2020; } \\
\text { Diterbitkan } 3 \text { April 2020. } \\
\text { ISSN: } \\
\text { 2723-0406 (media cetak) }\end{array}$ & 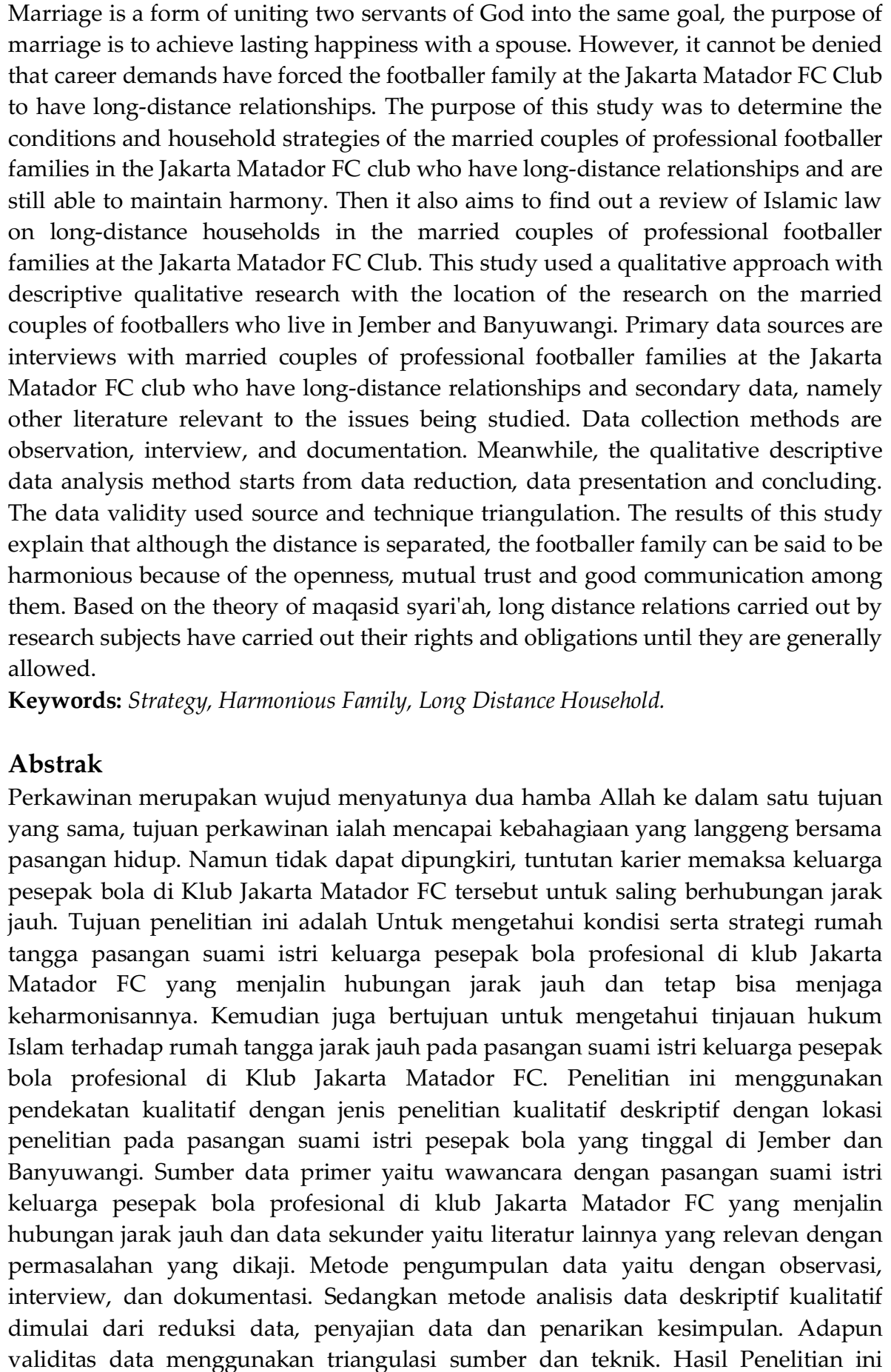 \\
\hline
\end{tabular}


menjelaskan bahwa walaupun terpisahkan jarak, keluarga pesepak bola tersebut dapat dikatakan harmonis sebab adanya keterbukaan, rasa saling percaya dan komunikasi yang baik di antaranya. Berdasarkan teori maqasid syari'ah, hubungan jarak jauh yang dilakukan oleh subjek penelitian sudah melaksanakan hak dan kewajibannya hingga secara umum diperbolehkan.

Kata Kunci: Strategi, Keluarga Harmonis, Rumah Tangga Jarak Jauh.

\section{Pendahuluan}

Manusia lahir dan diciptakan berpasang-pasangan, dan Allah mengkaruniai manusia dengan perasaan cinta, hawa nafsu, serta akal pikiran. Di samping itu fitrah manusia adalah sebagai makhluk sosial dimana ia tidak bisa hidup sendiri tanpa bantuan dari orang lain, sehingga antar manusia memiliki hubungan antara yang satu dengan yang lainnya. Salah satunya adalah dalam menjalin hubungan dengan lawan jenis. Hubungan ini terjalin karena pada dasarnya sifat manusia memiliki keinginan atau hasrat untuk saling mencintai dan dicintai oleh lawan jenis. Allah telah menciptakan manusia secara berpasang-pasangan supaya muncul suatu rasa ketenangan, kesenangan, ketenteraman, dan kebahagiaan. Hal ini sudah tertera dalam Al-Qur'an Surat Az-Zariyat ayat 49 yang berbunyi:

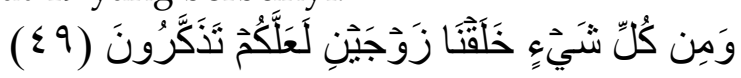

"Dan segala sesuatu Kami ciptakan berpasang-pasangan supaya kamu mengingat kebesaran Allah." (QS: Az-Zariyat: 49). ${ }^{1}$

Berdasarkan ayat Al-Qur'an tersebut disimpulkan, bahwa manusia itu diciptakan berpasang-pasangan untuk melakukan pernikahan yang bertujuan memenuhi tuntunan naluriah hidup manusia, berhubungan antara laki-laki dan perempuan dalam rangka mewujudkan kebahagiaan keluarga sesuai ajaran Allah dan Rasul-Nya. ${ }^{2}$

Pernikahan atau perkawinan adalah akad yang menghalalkan pergaulan dan membatasi hak dan kewajiban antara seorang laki-laki dan seorang perempuan yang bukan mahram. ${ }^{3}$ Sedangkan perkawinan menurut hukum Islam adalah pernikahan, akad yang sangat kuat atau mitssaqan ghalidzan untuk menaati perintah Allah dan melaksanakannya merupakan ibadah. ${ }^{4}$ Islam mensyariatkan dijalinnya pertemuan antara laki-laki dan perempuan, selanjutnya mengarah ke suatu pertemuan tersebut sehingga terlaksananya suatu pernikahan.

Pernikahan merupakan suatu yang diidam-idamkan oleh setiap orang, terlebih lagi gadis dan jejaka yang sedang memadu cinta. Menikah dan menjalani kehidupan pernikahan tentunya memiliki keinginan yang sama yakni ingin memiliki rumah tangga yang bahagia, harmonis, dan tenang. Pada dasarnya pernikahan merupakan penyatuan dua insan antara laki-laki dengan perempuan untuk membentuk rumah tangga yang harmonis dan sudah menjadi fitrah manusia untuk saling berpasang-pasangan.

Dalam Pasal (1) Undang-undang No. 1 Tahun 1974 tentang Perkawinan yaitu: Perkawinan adalah ikatan lahir dan batin antara seorang pria dengan seorang wanita sebagai suami istri dengan tujuan membentuk rumah tangga yang bahagia dan kekal berdasarkan ketuhanan Yang Maha Esa. Begitu juga disebutkan dalam Komplikasi Hukum Islam bahwa

\footnotetext{
${ }^{1}$ Departemen Agama RI, Al-Qur'an dan Terjemahannya, (Bandung: CV-Penerbit J-Art, 2004), 202.

2 Ahmad Azhar Basyir, Hukum Perkawinan Islam, (Yogyakarta: Uii Press, 2007), 11.

${ }^{3}$ Beni Ahmad Saebani, Fiqh Munakahat 1, (Bandung: Pustaka Setia, 2001), 9.

${ }^{4}$ Tim Redaksi Nuansa Aulia, Kompilasi Hukum Islam, (Bandung: CV. Nuansa Aulia, 2015), 2.
} 
perkawinan bertujuan untuk mewujudkan kehidupan Sakinah, Mawaddah, Warahmah. ${ }^{5}$ Berdasarkan pasal tersebut perkawinan mempunyai tujuan membentuk keluarga yang bahagia, harmonis, dan tenang.

Perkawinan merupakan perjanjian yang sangat sakral, bukan hanya karena sebagai perintah agama, namun juga tujuannya yang agung dan suci, karena perkawinan yang sah menurut agama merupakan bentuk wujud ketaatan seorang hamba kepada sang khaliq. ${ }^{6}$ Tujuan pernikahan menurut agama Islam sendiri yakni untuk memenuhi petunjuk agama dalam rangka mendirikan keluarga yang harmonis, sejahtera, dan bahagia. ${ }^{7}$

Keharmonisan kehidupan keluarga adalah berkumpulnya unsur fisik dan psikis yang berbeda antara pria dan wanita sebagai pasangan suami istri, yang dilandasi oleh berbagai unsur persamaan, seperti saling dapat memberi dan menerima cinta kasih yang tulus dan memiliki nilai-nilai yang serupa dalam perbedaan. Gunarsa mengatakan, keharmonisan keluarga adalah keadaan keluarga yang utuh dan bahagia, di dalamnya ada ikatan kekeluargaan yang memberikan rasa aman tenteram bagi setiap anggotanya. Selain itu adanya hubungan baik antara ayah-ibu, ayah-anak dan ibu-anak. ${ }^{8}$ Jadi dalam islam, keluarga yang harmonis itu adalah keluarga yang sakinah, mawaddah, warahmah. Atau bisa diartikan dengan keluarga yang damai, tenteram, penuh cinta kasih atau harapan dan kasih sayang yang selaras.

Dasar hukum keharmonisan yaitu didasari dari pernikahan yang mendambakan terciptanya rumah tangga yang sakinah, mawaddah dan warahmah (dipenuhi ketenangan, cinta, dan kasih sayang). Adapun dasar hukum Al-Quran:

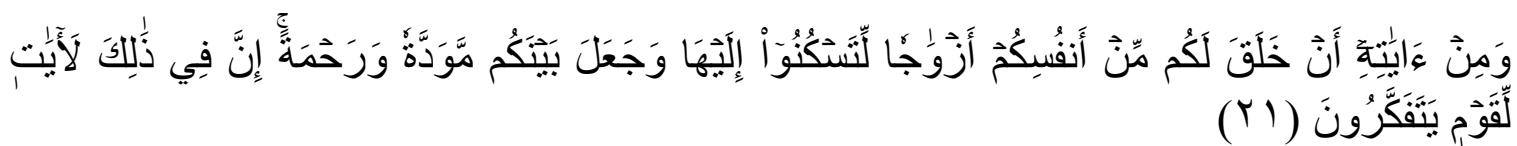

"Dan di antara tanda-tanda kekuasaan-Nya ialah Dia menciptakan untukmu isteri-isteri dari jenismu sendiri, supaya kamu cenderung dan merasa tenteram kepadanya, dan dijadikan-Nya di antaramu rasa kasih dan sayang. Sesungguhnya pada yang demikian itu benar-benar terdapat tanda-tanda bagi kaum yang berfikir." (QS. Ar-Rum: 21). ${ }^{9}$

Dalam ayat diatas jelaslah bahwa tujuan dari sebuah keluarga adalah untuk mencapai ketenangan, ketenteraman dan kebahagiaan. Keluarga merupakan suatu kelompok sosial yang bersifat langgeng berdasarkan hubungan pernikahan dan hubungan darah. ${ }^{10}$ Keluarga akan berjalan sesuai dengan peran dan fungsinya, jika anggota keluarga di dalamnya berperan menurut fungsinya masing-masing serta mampu menyikapi problem yang kerap kali menghampiri.

\footnotetext{
${ }^{5}$ Ibid.,73.

6 Khoirudin Nasution, Hukum Perkawinan 1: Dilengkapi Perbandingan Undang-Undang Negara Muslim, (Yogyakarta, Academia \& Tazzafa, 2005), 18.

7 Abdul Rahman Ghazaly, Figh Munakahat, (Jakarta: Kencana, 2006), 22.

${ }^{8}$ Mahmud Huda \& Anisatus Shalihah, (2016) “Keharmonisan Keluarga pada Nikah Siri dalam Praktik Poligami (Studi Kasus Di Kecamatan Lenteng Kabupaten Sumenep" Universitas Pesantren Tinggi Darul Ulum Jombang Indonesia diakses pada tanggal 23 Mei 2020.

9 Departemen Agama RI, Al-Qur'an dan Terjemahannya, 407.

${ }^{10}$ Yulia Singgih D. Gunarsa, Asas-Asas Psikologi Keluarga Idaman, (Jakarta Gunung Mulia, 2002), 43.
} 
Kebahagiaan di dalam keluarga tentulah menjadi salah satu tujuan yang ingin di peroleh meraka yang mendirikannya. ${ }^{11}$ Perkawinan merupakan wujud menyatunya dua hamba Allah ke dalam satu tujuan yang sama, tujuan perkawinan ialah mencapai kebahagiaan bersama pasangan hidup. Namun jalan menuju kebahagiaan tak selamanya mulus, banyak hambatan, rintangan dan persoalan yang terkadang menggagalkan jalannya rumah tangga, apalagi bagi pasangan suami istri yang menjalani pernikahan jarak jauh.

Kehidupan dalam suatu pernikahan dapat dilakukan dengan 2 (dua) model, yaitu dengan pernikahan jarak jauh (long distance marriage) ataupun tinggal dalam satu rumah (proximal marriage). Karena berbagai alasan seperti faktor ekonomi, pendidikan, ataupun karir, tidak jarang pasangan suami istri mengambil keputusan untuk menjalani pernikahan jarak jauh (long distance marriage). Pernikahan jarak jauh menurut Maines (1993) adalah pernikahan terpisah antara suami dengan istri yang didasari atas komitmen sebelum pernikahan karena tuntutan karir atau pekerjaan. ${ }^{12}$ Berdasarkan pengertian tersebut, pernikahan jarak jauh dilakukan pasangan suami istri semata-mata karena tuntutan karir/pekerjaan dan kebutuhan hidup dimana pasangan tersebut telah memiliki komitmen dan dapat menerima konsekuensi yang akan berimbas kepada keharmonisan rumah tangga.

Pada realitasnya dalam kehidupan rumah tangga banyak yang memiliki hubungan jarak jauh (long distance relationship) disebabkan salah satunya yaitu masalah karir, seperti pada keluarga pesepak bola profesional dimana hobi menjadi sebuah karir atau profesi (pekerjaan). Tak heran jika banyak keluarga pesepak bola profesional yang ada di Indonesia, dikarenakan sepakbola di Liga Indonesia sedang marak-maraknya apalagi dilihat dari segi gaji pesepak bola profesional dinilai sangat menggiurkan.

Sejak tahun 1994, Liga Indonesia adalah kompetisi liga yang menampilkan pertandingan antar klub sepak bola, sebagai hasil penggabungan dari dua kompetisi teratas di Indonesia yang sudah ada sebelumnya yaitu Perserikatan (amatir) dan Galatama (semi profesional). Liga Indonesia dikelola oleh Persatuan Sepakbola Seluruh Indonesia (PSSI) federasi sepak bola nasional Indonesia. Setelah mengalami beberapa revolusi sampai dengan saat ini, Liga Indonesia yang dikelola oleh PSSI terdiri 3 (tiga) yakni Liga 1 (satu), Liga 2 (dua) dan Liga 3 (tiga), dalam satu musimnya bisa mencapai 9 hingga 10 bulan dalam satu tahun. Dalam mengarungi satu musim kompetisi, suatu klub sepak bola profesional itu diwajibkan melakukan kontrak dengan para pemain untuk bisa secara resmi mengarungi sebuah kompetisi, dimana dalam mengontrak pemain tersebut dalam satu musim bisa mencapai 9 hingga 10 bulan bahkan separuh musim tergantung pada perjanjian kontrak di awal yang telah disepakati. ${ }^{13}$ Ketika kompetisi Liga Indonesia di mulai, suami dari istri keluarga pasangan pesepak bola profesional itu harus menjalani suatu hubungan jarak jauh demi tuntutan karir suami sebagai pesepak bola profesional untuk mencari nafkah bagi keluarganya.

\footnotetext{
${ }^{11}$ Hasan Basri, Merawat Cinta Kasih, (Yogyakarta: Pustaka Pelajar, 1996), 55.

${ }^{12}$ https://media.neliti.com/media/publications/104260-ID-model-komunikasi-perkawinan-jarak jauh.pdf > diakses pada tanggal 27 Februari 2019.

$13<$ https://id.wikipedia.org/wiki/Sistem_liga_sepak_bola_di_Indonesia > diakses pada tanggal 13 Mei 2019.
} 
Tidak dapat dipungkiri bahwa dalam perjalanannya, sebuah hubungan jarak jauh yang dialami pasangan suami istri keluarga pesepak bola profesional itu biasanya rentan akan terjadinya konflik. Hal ini dikarenakan terbatasnya waktu untuk bertemu, komunikasi yang tidak lancar, terjadinya kesalah pahaman dan sebagainya. Menjalani hubungan jarak jauh (suami istri tinggal terpisah) tidaklah mudah, masing-masing pasangan suami istri dari keluarga pesepak bola profesional harus mempunyai rasa saling percaya, kedewasaan sikap, tidak boleh egois, tidak boleh berwawasan sempit, harus selalu berpikir positif dan selalu berkomunikasi. Komunikasi merupakan salah satu faktor penting dalam kehidupan sebuah pernikahan, dan dalam hubungan jarak jauh tersebut tak luput adanya sebuah strategi untuk menjaga keharmonisan rumah tangganya. Masing-masing pasangan suami istri dari keluarga pesepak bola profesional itu, memiliki strategi tersendiri dalam menjaga keharmonisan rumah tangganya meski dalam menjalani hubungan jarak jauh.

Penulis memilih penelitian disalah satu klub sepak bola profesional di Indonesia yang terdaftar dalam anggota PSSI yakni klub Jakarta Matador FC. Jakarta Matador FC bermarkas di Stadion Lebak Bulus Jakarta Selatan yang berlaga di Kompetisi Liga 3 Indonesia. Jakarta Matador FC memiliki 25 (dua puluh lima) pemain sepak bola profesional yang dihuni oleh beberapa pemain senior dan junior. Sesuai dengan regulasi yang telah ditetapkan oleh PSSI, bahwasanya untuk Liga 3 Indonesia memakai pemain U-23 dan pemain senior 5 (lima) orang. ${ }^{14}$ Dari 25 (dua puluh lima) pemain tersebut terdapat 20 (dua puluh) pemain junior yang berusia U-23 ke bawah dan belum menikah serta 5 (lima) pemain senior yang sudah menikah. Dari 5 (lima) pemain senior itu berasal dari kota Jember dan Banyuwangi. ${ }^{15}$

Suami dari istri pesepak bola profesional itu menjalani hubungan jarak jauh, meninggalkan rumah dan istri bahkan anak-anaknya, demi mencari nafkah untuk keluarganya, tentunya dengan alasan untuk memperbaiki sistem perekonomian keluarga yang lebih baik. Sehingga dengan keadaan tersebut pasangan suami istri keluarga pesepak bola profesional yang ada di klub Jakarta Matador FC merekapun harus menjalani hubungan jarak jauh dalam rumah tangganya. Hal tersebut menjadikan intensitas pertemuan yang terbatas, sehingga pasangan ini memaksimalkan komunikasinya pada media telepon dan media sosial seperti whatsapp agar terjalin komunikasi yang baik dalam rumah tangganya.

Salah satu sampel yang diambil oleh penulis yakni Helmi Anshori yang berkediaman di Desa Panduman, Kecamatan Jelbuk, Kabupaten Jember. Helmi Anshori merupakan salah satu dari pemain senior di klub Jakarta Matador FC yang menjalani hubungan jarak jauh dengan istrinya namun mampu menjaga rumah tangganya tetap harmonis meskipun ada perselisihan dan percekcokan. ${ }^{16}$ Sebab itulah yang menjadi alasan peneliti tertarik ingin meneliti pada pasangan keluarga pesepak bola profesional yang tinggal jarak jauh dengan keadaan rumah tangga yang tetap harmonis dan bagaimana strategi untuk menjaga keharmonisannya tersebut.

\footnotetext{
$14<$ https://pssi.org/regulasi_liga 3 Indonesia > diakses pada tanggal 13 Mei 2019.

${ }^{15}$ Kantor Sekretariat Klub Jakarta Matador FC, Observasi, Jakarta Selatan, 27 Desember 2019.

${ }^{16}$ Helmi Anshori, Wawancara, Jelbuk Jember, 30 Mei 2019.
} 


\section{Rumusan Masalah}

Adapun rumusan masalah dalam penelitian ini adalah:

1. Bagaimana kondisi rumah tangga pasangan suami istri keluarga pesepak bola profesional di klub Jakarta Matador FC yang menjalin hubungan jarak jauh?

2. Bagaimana strategi pasangan suami istri keluarga pesepak bola profesional di klub Jakarta Matador FC yang menjalin hubungan jarak jauh dalam menjaga keharmonisan rumah tangganya?

3. Bagaimana tinjauan Hukum Islam terhadap rumah tangga jarak jauh pada pasangan suami istri keluarga pesepak bola profesional di Klub Jakarta Matador FC?

\section{Metode Penelitian}

Penelitian ini menggunakan pendekatan kualitatif, yaitu pengamatan, wawancara atau penelaahan dokumen. ${ }^{17}$ Penulis memilih jenis pendekatan ini dengan pertimbangan, yakni menyesuaikan metode kualitatif yang lebih mudah jika berhadapan langsung dengan kenyataan yang ada, dengan pendekatan ini penulis bisa menyajikan secara langsung hakikat hubungan antara penulis dan responden. Pendekatan ini juga lebih peka dan lebih dapat menyesuaikan diri terhadap pola-pola nilai yang dihadapi.

Jenis penelitian ini adalah lapangan (Field Reseach) yaitu penelitian yang objeknya mengenai gejala-gejala atau peristiwa-peristiwa yang terjadi pada kelompok masyarakat. Dengan pendekatan deskriptif kualitatif. Penelitian deskriptif adalah suatu penelitian yang bertujuan untuk membuat deskriptif atau gambaran mengenai fakta-fakta, sifat-sifat serta hubungan atau fenomena yang diselidiki. ${ }^{18}$ Sedangkan penelitian kualitatif adalah bertujuan untuk menghasilkan data deskriptif, berupa kata-kata lisan dari orang-orang dan perilaku mereka yang diamati. ${ }^{19}$ Dalam penelitian ini yang diteliti adalah pasangan suami istri keluarga pesepak bola profesional di klub Jakata Matador FC yang menjalani hubungan jarak jauh (LDR).

Adapun untuk sumber data, penulis menggunakan dua sumber yakni primer dan sekunder. Sumber data primer diperoleh dari individu atau perseorangan seperti hasil wawancara. Adapun sumber data primer yaitu peneliti melakukan wawancara kepada pasangan suami istri keluarga pesepak bola profesional di klub Jakarta Matador FC yang menjalin hubungan jarak jauh (LDR) diantaranya yaitu Muhammad Erik Isbiantono dan Anggie Restu Pratiwi, Helmi Anshori dan Suciati, Rasid Rasidi dan Mila Sartika, Imam Sanusi dan Rohmi Damayanti, Muhammad Ainur Rofiq dan Dita Damayanti Mahandika. Adapun alasan peneliti melakukan wawancara kepada ke lima informan pasangan suami istri tersebut karena jawaban mereka sudah mewakili dari semua populasi yang ada. Sumber data sekunder merupakan sumber data yang diperoleh dari pihak lain, yang berarti bahwa data tersebut didapatkan oleh peneliti tidak langsung diperoleh dari sumber pertama, melainkan data tersebut diperoleh dari buku-buku, skripsi, jurnal dan artikel-artikel yang memuat tentang pembahasan keluarga sakinah, rumah tangga jarak jauh (LDR) dan hal-hal lain yang masih terkait dengan penelitian ini.

Untuk Teknik pengumpuan data sendiri, penulis menggunakan teknik observasi, wawancara, dan dokumentasi. Dalam observasi penulis bisa mengetahui kondisi riil

\footnotetext{
17 Sugiyono, Metode Penelitian Kuantitatif, Kualitatif dan RED, (Bandung: Alfabeta, 2009), 2.

${ }^{18}$ Moh. Nasir, Metode Penelitian, (Jakarta: Ghalia Indonesia, 1999), 63.

${ }^{19}$ Lexy J. Moleong, Metodologi Penelitian Kualitatif: Edisi Revisi, (Bandung: Remaja Rosdakarya, 2012), 3.
} 
keharmonisan rumah tangga pasangan suami istri keluarga pesepak bola profesional di klub Jakarta Matador FC yang menjalin hubungan jarak jauh, serta mendapatkan data mengenai strategi menjaga keharmonisan rumah tangga jarak jauh dan informasi sebagai dasar analisis sehingga memberikan data yang akurat. Data yang dimaksud adalah data mengenai strategi. Dalam wawancara, penulis dapat mengetahui bagaimana strategi yang digunakan oleh pasangan suami istri keluarga pesepak bola profesional di klub Jakarta Matador FC dalam menjaga keharmonisan rumah tangganya walaupun dalam keadaan jarak jauh. Serta dokumentasi digunakan untuk mengetahui sejarah klub Jakarta Matador FC, profil klub Jakarta Matador FC, visi misi dan tujuan klub Jakarta Matador FC, serta struktur managemen klub Jakarta Matador FC, sehingga menambah kredibel data dalam penelitian.

Teknik analisis data yang digunakan dalam penelitian ini adalah analisis diskriptif kualitatif. Dalam analisis kualitatif ada tiga komponen analisa yaitu reduksi data, penyajian data, dan penarikan kesimpulan dan verifikasi. Aktifitasnya dilakukan dalam bentuk interaksi dengan proses pengumpulan data sebagai suatu siklus. ${ }^{20}$ Analisis data dalam penelitian kualitatif, dilakukan pada saat pengumpulan data berlangsung, dan setelah selesai pengumpulan data dalam periode tertentu. Pada saat wawancara, peneliti sudah melakukan analisis terhadap jawaban yang diwawancarai. Bila jawaban yang diwawancarai setelah dianalisis terasa belum memuaskan, maka peneliti akan melanjutkan pertanyaan lagi, sampai tahap tertentu, diperoleh data yang dianggap kredibel. ${ }^{21}$

\section{Kondisi Rumah Tangga Pasangan Suami Istri Keluarga Pesepak Bola Profesional di Klub Jakarta Matador FC yang Menjalin Hubungan Jarak Jauh}

Dari hasil analisis data, penulis memandang dan memahami bahwa kondisi rumah tangga pasangan suami istri keluarga pesepak bola profesional di klub Jakarta Matador FC bahwa faktor yang melatar- belakangi mereka bekerja sebagai pesepak bola profesional dan rela menjalani hubungan jarak jauh dengan istri dan anak-anaknya, yaitu faktor ekonomi. Mereka tidak bisa bertahan dengan profesi sebagai petani, buruh tani dan penjaga toko sembako, karena dirasa belum cukup untuk memenuhi kebutuhan dan mewujudkan impian mereka. Mereka juga mempunyai keinginan yang besar untuk memiliki rumah sendiri, untuk mewujudkan keinginan menyejahterakan keluarganya, membantu kedua orang tuanya, hingga menyekolahkan anaknya ke jenjang yang lebih tinggi, maka suami mereka memutuskan untuk bekerja sebagai pesepak bola profesional di klub Jakarta Matador FC meskipun harus berjauhan dengan istri dan anak-anaknya.

Meskipun terkadang ada rasa rindu, bosan, dan khawatir serta takut saat sedang berhubungan jarak jauh, namun setelah dijalani dan sudah terbiasa hasilnya rumah tangga mereka tetap utuh dan harmonis. Meskipun pernah terjadi perselisihan dan percekcokan, tetapi tidak ada yang sampai melakukan perceraian, karena masalah kurangnya kasih sayang dan pengawasan terhadap anak serta kepuasaan pernikahan. Bagi istri yang ditinggal bekerja ke luar kota oleh sang suami dan mengurus anak tanpa suami yang mendampingi, mereka para istri tidak mempermasalahkan hal itu, karena yang terpenting sang suami tetap punya

\footnotetext{
${ }^{20}$ Miles dan Huberman, Metode Penelitian Kualitatif, (Jakarta: Gramedia, 2002), 68.

21 Ibid, 246.
} 
tanggung jawab untuk menafkahi istri dan anak-anaknya dengan mentransfer uang hasil pekerjaannya.

Kekhawatiran seseorang terhadap pasangannya itu hal yang lazim apalagi bagi pasangan suami istri yang berjauhan karena takut kehilangan orang yang ia cintai dan sayangi. Bagi pasangan suami istri pada keluarga pesepak bola profesional di klub Jakarta Matador FC yang menjalin hubungan jarak jauh sudah terbiasa. Meskipun kadang rasa rindu itu ada tapi mereka bisa menepis semua itu dengan cara mereka.

Pasangan tentu memiliki impian serta keinginan menyejahterakan keluarganya dan memenuhi segala kebutuhan istri dan anaknya, namun setelah mereka memutuskan untuk beralih profesi dari petani, buruh tani serta penjaga toko sembako menjadi profesi pesepak bola profesional, keadaan rumah tangga mereka sedikit demi sedikit mulai berubah. Impian ingin memiliki rumah sendiri sedikit banyak dapat terwujud dan kebutuhan-kebutuhan istri dan anak yang sebelumnya tidak dapat terpenuhi akhirnya bisa terpenuhi.

\section{Strategi Menjaga Keharmonisan Rumah Tangga Pasangan Suami Istri Keluarga Pesepak Bola Profesional di Klub Jakarta Matador FC yang Menjalin Hubungan Jarak Jauh}

Dari hasil analisis data, penulis memandang dan memahami bahwa hubungan pasangan suami istri pada keluarga pesepak bola profesional di klub Jakarta Matador FC dijalin melalui hubungan jarak jauh, akan tetapi keharmonisan rumah tangga mereka selalu terjaga meskipun pernah terjadi perselisihan dan percekcokan seperti terjadi kesalah fahaman yang disebabkan rasa cemburu, dan kecurigaan atau berprasangka buruk terhadap pasangan, serta masalah kurangnya intensitas pertemuan, kurangnya kasih sayang dan pengawasan terhadap anak hingga kepuasaan pernikahan. Meskipun begitu, mereka bisa mengatasi dan menyelesaikan dengan secara baik-baik, karena mereka berkomitmen untuk mempertahankan keharmonisan dan keutuhan rumah tangganya. Mereka selalu mengatasi perselisihan dan percekcokan dalam rumah tangganya dengan baik dengan cara saling menanamkan rasa saling percaya, komitmen yang kuat dan keterbukaan antara suami istri, serta tetap menjaga komunikasi dengan menelfon dan video call setiap hari dua kali terkadang tiga kali, atau jika ada jatah libur itu digunakan untuk pulang ke rumah demi mengobati rasa kerinduan terhadap keluarganya. Mereka juga tetap menjalankan kewajibannya terhadap pasangan masing-masing, suami tetap menafkahi istrinya dengan cara mentransfer uang hasil pekerjaannya untuk kebutuhan keluarga dan pendidikan anak, dan sebagai istri tetap menjalani kewajibannya dengan menjaga kehormatan keluarganya. Kewajiban istri yang ditinggal oleh suami bekerja sebagai pesepak bola profesional yakni mengasuh anak dengan baik, menjaga harta suami dan menjaga kehormatan keluarga, serta berkomitmen untuk mempertahankan keharmonisan dan keutuhan rumah tangganya, itulah sebuah dasar dalam sebuah hubungan hingga keharmonisan rumah tangga tetap terjaga.

Komitmen memiliki peranan yang sangat penting dalam sebuah hubungan, baik itu hubungan jarak dekat maupun jarak jauh. Karena komitmen merupakan perwujudan dari niat tulus dalam menjalin hubungan. Jarak dan waktu bukan lagi menjadi masalah yang besar untuk menjalani kehidupan bersama pasangan, asalkan ada komitmen diantara keduanya.

Pasangan suami istri keluarga pesepak bola profesional di klub Jakarta Matador FC yang menjalin hubungan jarak jauh selain berkomitmen untuk mempertahankan keutuhan dan keharmonisan rumah tangganya, mereka juga menanamkan rasa saling percaya. Mereka 
memahami jika dalam suatu hubungan selalu ada kecurigaan terhadap gerak-gerik pasangan yang menyebabkan rasa tidak nyaman dalam sebuah hubungan. Menanamkan rasa saling percaya itu sangatlah penting, mengingat tidak dapat selalu memantau keberadaan pasangan serta aktivitas apa saja yang dilakukannya dan dengan siapa saja ia melakukannya, begitu juga sebaliknya. Kecurigaan yang berlebihan justru akan membawa hubungan ke arah keretakan dan bahkan kehancuran. Dengan saling menanamkan rasa saling percaya maka akan merasa tenteram dalam menjalani hari-hari masing-masing.

Menjalani hubungan jarak jauh merupakan hal biasa bagi pasangan suami istri keluarga pesepak bola profesional di klub Jakarta Matador FC, namun untuk menjalani hal itu dengan waktu yang lama dan jarak yang jauh bukanlah suatu hal yang mudah karena mereka harus menahan rindu, kesepian di setiap waktu, namun dengan rasa sabar mereka mampu melaluinya. Kesabaran dalam rumah tangga sangatlah penting karena dalam kehidupan rumah tangga banyak sekali cobaan dan ujian. Maka perlu diingat Allah akan menggantikan kepada kita sebuah kebaikan, setelah cobaan itu datang.

Sebagai umat muslim, dalam kajian tentang akhlak, kita menemukan besarnya perhatian akan masalah kesabaran. Al-Qur'an mendorong kita ke arah kesabaran dalam semua aspek kehidupan. Untuk para pasangan suami istri yang berjauhan juga diharapkan tidak pernah lupa untuk selalu bersyukur atas nikmat Allah, meskipun mereka harus bertempat tinggal berbeda atau terpisahkan jarak dengan pasangan mereka. Dengan bersyukur dan bersabar semua yang terjadi akan lebih mudah dilalui, karena dengan bersyukur dan bersabar mendatangkan ketenangan bagi jiwa.

Dalam menjaga keharmonisan rumah tangga, pasangan suami istri yang berjauhan harus tetap saling terbuka, karena menurut mereka dengan merahasiakan suatu hal dari pasangan akan berdampak negatif terhadap keharmonisan rumah tangga. Keterbukaan diri menjadi salah satu komponen yang paling penting dalam menyesuaikan kehidupan perkawinan. Pasangan harus mau saling bercerita mengenai banyak hal tanpa diminta ataupun sebagai respons balik selama berkomunikasi.

Dalam menjaga sebuah hubungan apalagi bagi pasangan suami istri yang berjauhan bukanlah lah yang mudah, akan tetapi perlu adanya komponen-komponen yang akan menjadi penopang untuk mempertahankan sebuah hubungan rumah tangga, terutama yang harus terpisahkan jarak, karena dalam menjalani hubungan jarak jauh pasti akan berdampak pada setiap pasangan baik itu dampak positif atau negatif. Di antaranya dampak positif bagi pasangan yang berjauhan yaitu pasangan akan tahu bagaimana cara menghargai waktu, segala kebutuhan materi akan terpenuhi, kehidupan rumah tangga pasangan akan makin mesra dan anak akan lebih termotivasi untuk belajar karena melihat ayahnya pergi untuk berkorban demi dirinya, serta jarang terjadi konflik karena jarang bertemu. Adapun dampak negatif bagi pasangan yang berjauhan di antaranya yaitu merasa kesepian, keintiman berkurang (kepuasan pernikahan), rasa curiga yang tak berujung dan peluang selingkuh semakin luas.

Untuk meminimalisir timbulnya dampak negatif terhadap suatu hubungan jarak jauh, maka para pasangan suami istri keluarga pesepak bola profesional di klub Jakarta Matador FC tetap menjaga komunikasi dengan pasangannya, karena bagi mereka komunikasi sangat penting dalam sebuah hubungan apalagi bagi pasangan yang berjauhan. Tanpa adanya komunikasi kehidupan rumah tangga akan terasa sunyi, tak ada perbincangan dan tidak dapat mengetahui kabar pasangannya. Karena komunikasi dalam keluarga mengacu pada pertukaran informasi secara lisan dan bahasa tubuh antara anggota keluarga. Komunikasi 
melibatkan kemampuan untuk memperhatikan apa-apa yang disampaikan, dipikirkan dan dirasakan oleh orang lain. Dengan kata lain, bagian terpenting dari komunikasi keluarga tidak semata-mata hanya berbicara, namun menyimak apa yang akan dikatakan oleh orang lain. Tanpa komunikasi, kehidupan keluarga akan terasa sepi karena di dalamnya tidak ada kegiatan berbicara, berdialog, bertukar pikiran, dan sebagainya. Tanpa adanya komunikasi, kerawanan hubungan antara orang tua dan anak sukar untuk dihindari. Oleh karena itu, komunikasi merupakan sesuatu yang esensial dalam kehidupan keluarga.

Sebagai suami-istri tentu memiliki hak dan kewajiban bersama meskipun sedang berjauhan. Hak dan kewajiban tersebut tetap harus dilaksanakan, guna mempertahankan keharmonisan rumah tangga. Pasangan suami istri keluarga pesepak bola profesional di klub Jakarta Matador FC meskipun berjauhan tetap melakukan kewajibannya. Sebagai suami, mereka menafkahi istri dengan cara mentransfer setiap hasil pekerjaannya ditransfer untuk membiayai pendidikan anak, serta biaya rumah tangga, biaya perawatan dan pengobatan bagi istri dan anak seperti yang sudah tertulis dalam Undang-Undang Nomor 1 Tahun 1974 tentang perkawinan tercantum dalam pasal 80. Sebagai seorang istri meskipun berjauhan dengan suami tentunya juga harus melaksanakan kewajiban, diantaranya yaitu mendidik dan memelihara anak dengan baik dan penuh dengan tanggung jawab, menghormati serta menaati suami, menjaga kehormatan keluarga serta menjaga dan mengatur pemberian suami (nafkah suami) untuk mencukupi kebutuhan keluarga, mengatur dan mengurusi rumah tangga demi kesejahteraan dan kebahagiaan keluarga.

\section{Tinjauan Hukum Islam Terhadap Rumah Tangga Jarak Jauh pada Pasangan Suami Istri Keluarga Pesepak Bola Profesional di Klub Jakarta Matador FC}

Ditinjau dari hukum Islam, rumah tangga jarak jauh yang dilakukan pasangan suami istri keluarga pesepak bola profesional tersebut sebagian besar sudah sesuai dengan hukum islam. Para suami sudah melaksanakan kewajibannya sesuai dengan hukum Islam, seperti kewajiban memberi nafkah kepada anak dan istrinya meskipun dengan cara mentransfer, kewajiban memberikan tempat tinggal, bergaul dengan baik terhadap keluarganya, serta mendidik istri. Sedangkan kewajiban memimpin istri tidak sesuai dengan hukum Islam, karena kepemimpinan suami hanya bersifat bayangan ketika suami sedang bekerja di luar kota sebagai pesepak bola profesional.

Semua istri juga dapat menjalankan kewajibannya sesuai dengan hukum Islam, seperti menjaga kehormatan diri, mengasuh anak dengan baik, menjaga harta suami dan menjaga kehormatan keluarga serta taat kepada suami dan tidak keluar rumah tanpa izin suami. Walaupun pada kewajiban untuk meminta izin ketika keluar rumah, istri tidak selalu meminta izin dan hanya izin ketika ada kepentingan yang lebih penting, akan tetapi suami sudah ridho dan memakluminya.

Dalam pelaksanaan hak dan kewajiban bersama, para suami dan istri telah melaksanakannya sesuai dengan hukum Islam. Walaupun terkendala jarak dan waktu, tetapi kewajiban bersama, seperti saling menjaga amanah, saling memberikan cinta dan kasih sayang, kerja sama membina rumah tangga dapat berjalan dengan baik. Suami dan istri tetap menjalankan kewajibannya sebagaimana mestinya, berkomitmen untuk tetap menjaga keharmonisan dan keutuhan rumah tangganya meskipun menjalin hubungan jarak jauh. Hal ini terbukti dengan tetap rukunnya rumah tangga tersebut walaupun harus berumah tangga 
jarak jauh. Percekcokan serta perselisihan pasti pernah terjadi, namun mereka mengatasinya dengan cara mereka tersendiri. Mereka juga dapat memenuhi kebutuhan-kebutuhan yang belum terpenuhi, memperbaiki sistem perekonomian keluarga dan bisa mewujudkan impian mereka yaitu memiliki rumah sendiri serta menyekolahkan anaknya ke jenjang yang lebih tinggi.

Berdasarkan teori maqasid syari'ah, pasangan suami-istri keluarga pesepak bola profesional di Klub Jakarta Matador FC telah dapat melaksanakan hak dan kewajibannya untuk memelihara agama, memelihara jiwa, memelihara akal, memelihara keturunan, dan memelihara harta, sehingga dapat disimpulkan bahwa rumah tangga jarak jauh pada pasangan suami istri keluarga pesepak bola profesional di Klub Jakarta Matador FC diperbolehkan.

\section{Kesimpulan}

Setelah memberikan pengantar dan gambaran dalam menganalisis beberapa permasalahan-permasalahan yang diteliti, maka ditarik kesimpulan sebagai berikut:

1. Kondisi rumah tangga pasangan suami istri keluarga pesepak bola profesional di klub Jakarta Matador FC dapat dikatakan harmonis, walaupun seperti rumah tangga lainnya pasti mengalami fase perselisihan mereka dapat menyelesaikannya secara baik-baik dan tidak ada yang sampai melakukan perceraian. Bagi istri yang ditinggal bekerja ke luar kota sebagai pesepak bola profesional di klub Jakarta Matador FC oleh sang suami dan mengurus anak tanpa suami yang mendampingi, mereka para istri tidak mempermasalahkan hal itu, karena yang terpenting sang suami tetap punya tanggung jawab untuk menafkahi istri dan anak-anaknya dengan mentransfer uang hasil pekerjaannya. Setelah mendapatkan hasil dari bekerjanya sebagai pesepak bola profesional akhirnya mereka dapat memenuhi kebutuhan-kebutuhan, memperbaiki perekonomian rumah tangga dan bisa mewujudkan impian mereka yaitu memiliki rumah sendiri tanpa harus menumpang dengan orang tua.

2. Strategi dalam menjaga keharmonisan rumah tangga jarak jauh yang pasangan suami istri keluarga pesepak bola profesional di klub Jakarta Matador FC adalah harus saling menanamkan rasa saling percaya, komitmen yang kuat dan keterbukaan antara suami istri, serta tetap menjalankan kewajibannya terhadap pasangan masing-masing. Selalu sabar atas segala ujian dalam rumah tangga dan selalu bersyukur pun menjadi slaah satu strategi, karena dengan selalu bersyukur semua yang terjadi akan lebih mudah dilalui dan mendatangkan ketenangan bagi jiwa. Dalam menjaga keharmonisan rumah tangga jarak jauh harus sama-sama saling terbuka antara suami dan istri, karena keterbukaan menjadi salah satu komponen yang sangat penting dalam menyesuaikan diri dengan kehidupan perkawinan hingga keharmonisan rumah tangga selalu terjaga. Selain itu, pasangan harus tetap menjaga komunikasi karena komunikasi dalam keluarga sangatlah penting untuk meminimalisir timbulnya dampak negatif hubungan jarak jauh terhadap suami dan istri. 
3. Ditinjau dari hukum Islam, rumah tangga jarak jauh pada pasangan suami istri keluarga pesepak bola profesional di Klub Jakarta Matador FC tersebut sebagian besar sudah sesuai dengan hukum islam. Para suami sudah melaksanakan kewajibannya sesuai dengan hukum Islam, seperti kewajiban memberi nafkah kepada anak dan istrinya, kewajiban memberikan tempat tinggal, bergaul dengan baik terhadap keluarganya serta mendidik istri. Sedangkan kewajiban memimpin istri tidak sesuai dengan hukum Islam, karena kepemimpinan suami hanya bersifat bayangan ketika suami sedang bekerja di luar kota sebagai pesepak bola profesional. Semua istri juga dapat menjalankan kewajibannya sesuai dengan hukum Islam, seperti menjaga kehormatan diri, mengasuh anak dengan baik, menjaga harta suami dan menjaga kehormatan keluarga, taat kepada suami dan tidak keluar rumah tanpa izin suami. Berdasarkan teori maqasid syari'ah, pasangan suami istri keluarga pesepak bola profesional di Klub Jakarta Matador FC telah dapat melaksanakan hak dan kewajibannya untuk memelihara agama, memelihara jiwa, memelihara akal, memelihara keturunan, dan memelihara harta, sehingga dapat disimpulkan bahwa rumah tangga jarak jauh pada pasangan suami istri keluarga pesepak bola profesional di Klub Jakarta Matador FC diperbolehkan.

\section{Daftar Pustaka}

\section{Buku}

Arikunto, Suharsimi. 2010. Prosedur Penelitian. Jakarta: PT Rineka Cipta.

Basri, Hasan. 1996. Merawat Cinta Kasih. Yogyakarta: Pustaka Pelajar.

Basyir, Ahmad Azhar. 2007. Hukum Perkawinan Islam. Yogyakarta: Uii Press.

Creswell, Jhon W. 2016. Research Design Pendekatan Kualitatif, Kuantitatif dan Mixed. Yogyakarta: Pustaka Pelajar.

Departemen Agama RI. 2004. Al-Qur'an dan Terjemahannya. Bandung: CV-Penerbit J-Art.

Ghazaly, Abdul Rahman. 2006. Figh Munakahat. Jakarta: Kencana.

Gunarsa, Yulia Singgih D. 2002. Asas-Asas Psikologi Keluarga Idaman. Jakarta: Gunung Mulia.

Miles dan Huberman. 2002. Metode Penelitian Kualitatif. Jakarta : Gramedia.

Moleong, Lexy J. 2012. Metodologi Penelitian Kualitatif: Edisi Revisi. Bandung: Remaja Rosdakarya.

Mushaf Al-Majid. Al-Qur'an dan Terjemahannya. Jakarta : Pustaka Al-Mubin.

Nasir, Moh. 1999. Metode Penelitian. Jakarta: Ghalia Indonesia.

Nasution, Khoirudin. 2005. Hukum Perkawinan 1: Dilengkapi Perbandingan Undang-Undang Negara Muslim. Yogyakarta : Academia \& Tazzafa.

Saebani, Beni Ahmad. 2001. Fiqh Munakahat 1. Bandung: Pustaka Setia.

Sugiono, 2013. Metode Penelitian Kuantitatif, Kualitatif dan RED, cet 19. Bandung: CV Alfabeta.

Sugiyono. 2009. Metodologi Penelitian Kuantitatif, Kualitatif RED. Bandung: Alfabeta.

Suharto, Babun dkk. 2017. Pedoman Penulisan Karya Ilmiah. Jember: IAIN Jember Press.

Suhiyono. 2016. Metode Penelitian Kuantitatif, Kualitatif dan RED. Bandung: Alfabeta.

Tim Redaksi Nuansa Aulia. 2015. Kompilasi Hukum Islam. Bandung: CV. Nuansa Aulia.

Umar, Husain. 2000. Metode Penelitian Untuk Skripsi Tesis dan Bisnis. Jakarta: Raja Grafindo Persada. 


\section{Jurnal}

Huda, Mahmud \& Shalihah, Anisatus. 2016. "Keharmonisan Keluarga pada Nikah Siri dalam Praktik Poligami (Studi Kasus di Kecamatan Lenteng Kabupaten Sumenep". (Universitas Pesantren Tinggi Darul Ulum Jombang Indonesia). Jurnal. 23 Mei 2020.

\section{Internet}

https://id.wikipedia.org/wikipediaSistem liga sepak_bola_di_Indonesia diakses pada tanggal 13 Mei 2019.

https://media.neliti.com/media/publications/104260-ID-modelkomunikasi-perkawinan-jarakjauh.pdf di akses pada tanggal 27 Februari 2019.

https://pssi.org/regulasi_liga_3 Indonesia diakses pada tanggal 13 Mei 2019.

\section{Perundang-undangan}

Undang-undang No. 1 Tahun 1974 tentang Perkawinan. 